\title{
Density, Biotope Distribution and Ecological Groups of Bivalve Mollusks in the Access Channels to Tuyatortar and Jizzakh Reservoirs
}

\author{
X. T. Boymurodov ${ }^{1 *}$ and I. A. Toynazarova ${ }^{2}$ \\ ${ }^{1}$ Samarkand State University, \\ ${ }^{2}$ Independent researcher of Jizzakh Polytechnic Institute \\ *Corresponding author
}

A B S T R A C T

Keywords

Tuyatortar, Jizzakh, Sinanodonta gibba, S. orbicularis, $S$. puerorum, Channels, Bivalve mollusks, Density, Biotopes, Distribution, Ecological group

Article Info

Accepted:

12 January 2021

Available Online:

10 February 2021
10 species and 2 subspecies of bivalve mollusks were found in the Tuyatortar channel, 8 species and 2 subspecies were found in the Jizzakh channel. Eight species of peloreophiles (Corbicula cor, S. purpurea, S.fluminalis, Corbiculina tibetensis, C.ferghanensis, Sinanodonta gibba, S.orbicularis, $S$. puerorum) are commonly met in Tuyatortar channel, accounting for $67 \%$ of the total mollusks. Rheophiles include 2 species (Colletopterum syreum sogdianum, C. bacterianum) (16.5\%), 2 species (Colletopterum ponderosum volgense, Colletopterum kokandicum), pelolemnofil accounts for $16.5 \%$.

\section{Introduction}

In aquatic ecosystems, bivalve mollusks are a complex group for research. The simplicity of their shell shape, the presence or absence of teeth help to identify them in scientific researches. Bivalve mollusks Accounts for the main mass among benthic organisms in aquatic ecosystems. Their distribution, the large number of individuals play an important role in the study of zoogeography problems, the history of freshwater fauna, the study of hydrobiology, environmental monitoring, bioindication and ecosystems.

As a result of pollution of aquatic ecosystems, underwater biocenoses are radically changing, with local species being replaced by other common new species. Bivalve mollusks play an important role in the purification of contaminated water among invertebrates. They pass water through the whole body and 
filter it, that is to say these mollusks are natural water purifiers. Today, the study of the density, distribution and ecological groups of bivalve mollusks in the Tuyatortar and Jizzakh reservoirs is one of the most pressing issues of research.

The rate of the scientific studied issue. Unionidae ва Corbiculidae families have been learned by James H.Thorp, Alanp Covich, Aldridge, Bouchet, Huber Markus, Bogan, Annabelle Cuttelod, Maria Haws, Mamangkey, Rahayu,Sata Yoshida Srie Rahayu [1,2,3].

In Uzbekistan, Izzatullaev IZ and Boymuradov HT conducted researches on the inventory of bivalve mollusks in water bodies, to determine the distribution and characteristics of them in reservoirs, to study the current state of populations of rare and endemic species.

\section{Materials and Methods}

86 samples from the channels were studied, including 324 molluscs. Samples of these mollusks are systematically studied, in the investigations of Ploxinsky in 1970; Rijinashvili in 2005; Starobogatov, Izzatullaev in 1984, Izzatullaev, Boymurodov in 2009. They used various kind of methods.

\section{Results and Discussion}

The density rate of bivalve mollusks, their distribution rate in biotopes, and their ecological groups that occur in the access channels to Tuyatortar and Jizzakh reservoirs have been learned in the following article.

Tuyatortar channel is an ancient one which is located in Samarkand and Jizzakh regions. It starts from the First May (Birinchi May) dam on the right side of the Zarafshan river, and flows into the Sangzar river. Until recently, mollusks from this channel and its surrounding water types have not been studied.

As a result of our research, 10 species of mollusks and 2 subspecies of mollusks were found to live in the area around this canal, which belong to 2 families and 4 species (Table 1). They are distributed in rocky soils (2), sandy soils (5) and muds (10), depending on the specific characteristics of the channel.

The inflow of Zarafshan water into the Sangzar River through the Tuyatortar channel and the passage of biphasic mollusks along the water along the Zarafshan bank led to their distribution in the Sangzar river aquifer, the expansion of their range. As can be seen from Table 1, bivalve mollusks in the initial part of the Tuyatortar channel are characterized by a large number of species and densities. In the middle part Sinanodonta orbicularis, S.ruerorum occur in 1.2-1.5 per $1 \mathrm{~m} 2$.

But these species are not found in the bay. Z.I.Izzatullaev's 1980-1992 researches did not show the species Sinanodonta gibba, S.orbicularis and S.ruerorum from this region $[4,5]$. However, research has shown that these species are distributed in the middle part of the Sangzordarya - Karavultepa and Jizzakh reservoirs. It should be noted that the gloxidia of Sinanodonta seed species are ecoparasitic for some time in fish for reproduction and propagation.

These species are native to the territory of China and are associated with the development of fisheries in our country for the reproduction of non-traditional Chinese complex fish species infested with Sinanodonta gloxidia - white amur (Ctenopharyngodon idella) and whitefish (Hypophthalmichthys molitrix). 
Table.1 Density, biotope distribution and ecological groups of bivalve mollusks in the access channels to Tuyatortar Reservoirs

\begin{tabular}{|c|c|c|c|c|c|c|c|c|}
\hline \multirow[t]{2}{*}{ № } & \multirow[t]{2}{*}{ Types } & \multicolumn{3}{|c|}{ Density in channel currents, $\mathbf{m}^{2}$} & \multicolumn{3}{|c|}{ Biotopes } & \multirow[t]{2}{*}{ Ecological types } \\
\hline & & Beginning points & Middle & Bottom places & $\begin{array}{l}\text { Rocky } \\
\text { places }\end{array}$ & $\begin{array}{l}\text { Sandy } \\
\text { places }\end{array}$ & Muds & \\
\hline 1. & Sinanodonta gibba & $2,2 \pm 0,2$ & - & - & - & - & + & Peloreophil \\
\hline 2. & Sinanodontaorbicularis & $2,3 \pm 0,3$ & $1,5 \pm 0,2$ & - & - & - & + & Peloreophil \\
\hline 3. & Sinanodonta puerorum & $1,7 \pm 0,1$ & $1,2 \pm 0,3$ & - & - & - & + & Peloreophil \\
\hline 4. & Colletopterum bactrianum & $0,8 \pm 0,1$ & - & - & - & - & + & Reophil \\
\hline 5. & Colletopterum cyreum sogdianum & $2,4 \pm 0,4$ & $1,8 \pm 0,4$ & - & - & - & + & Reophil \\
\hline 6. & Colletopterum ponderosum volgense & $1,1 \pm 0,1$ & - & - & - & - & + & Pelolimnofil \\
\hline 7. & Colletopterum kokandicum & $0,7 \pm 0,1$ & - & - & - & - & + & Pelolimnofil \\
\hline 8. & Corbicula cor & $2,4 \pm 0,3$ & $1,1 \pm 0,2$ & - & - & + & - & Peloreophil \\
\hline 9. & Corbicula fluminalis & $2,2 \pm 0,2$ & $1,6 \pm 0,3$ & $1,2 \pm 0,3$ & - & + & + & Peloreophil \\
\hline 10. & Corbicula purpurea & $2,5 \pm 0,4$ & $2,1 \pm 0,2$ & - & + & + & - & Peloreophil \\
\hline 11. & Corbiculina tibetensis & $3,3 \pm 0,6$ & $2,7 \pm 0,4$ & $1,1 \pm 0,1$ & - & + & + & Peloreophil \\
\hline 12. & Corbiculina ferghanensis & $3,5 \pm 0,5$ & $2,8 \pm 0,3$ & $1,4 \pm 0,1$ & + & + & + & Peloreophil \\
\hline \multicolumn{2}{|r|}{ Total: } & 12 & 8 & 3 & 2 & 5 & 10 & \\
\hline
\end{tabular}

Table.2 Density, biotope distribution and ecological groups of bivalve mollusks in the access channels to Jizzakh Reservoirs

\begin{tabular}{|c|c|c|c|c|c|c|c|c|}
\hline \multirow[t]{2}{*}{ № } & \multirow[t]{2}{*}{ Types } & \multicolumn{3}{|c|}{ Density in channel currents, $\mathbf{m}^{2}$} & \multicolumn{3}{|c|}{ Biotopes } & \multirow[t]{2}{*}{ Ecological types } \\
\hline & & $\begin{array}{l}\text { Beginning } \\
\text { points }\end{array}$ & Middle & Bottom places & $\begin{array}{l}\text { Rocky } \\
\text { places }\end{array}$ & $\begin{array}{l}\text { Sandy } \\
\text { places }\end{array}$ & Muds & \\
\hline 1. & Sinanodonta gibba & $1,1 \pm 0,1$ & - & $0,9 \pm 0,1$ & - & - & + & Peloreophil \\
\hline 2. & Sinanodontaorbicularis & $1,4 \pm 0,2$ & - & $1,2 \pm 0,3$ & - & - & + & Peloreophil \\
\hline 3. & Sinanodonta puerorum & $1,6 \pm 0,3$ & - & - & - & - & + & Peloreophil \\
\hline 4. & Colletopterum bactrianum & - & - & - & - & - & + & Reophil \\
\hline 5. & Colletopterum cyreum sogdianum & $1,1 \pm 0,1$ & - & - & - & - & + & Reophil \\
\hline 6. & Colletopterum ponderosum volgense & $0,5 \pm 0,1$ & - & $0,8 \pm 0,1$ & - & - & + & Pelolimnofil \\
\hline 7. & Colletopterum kokandicum & - & - & $0,6 \pm 0,1$ & - & - & + & Pelolimnofil \\
\hline 8. & Corbicula cor & $1,6 \pm 0,4$ & $1,1 \pm 0,3$ & $1,4 \pm 0,2$ & - & + & - & Peloreophil \\
\hline 9. & Corbicula fluminalis & $1,5 \pm 0,3$ & - & $1,5 \pm 0,2$ & - & + & - & Peloreophil \\
\hline 10. & Corbicula purpurea & $1,3 \pm 0,2$ & - & $1,4 \pm 0,3$ & + & + & - & Peloreophil \\
\hline 11. & Corbiculina tibetensis & $2,1 \pm 0,3$ & $1,1 \pm 0,3$ & $2,0 \pm 0,3$ & + & - & + & Peloreophil \\
\hline 12. & Corbiculina ferghanensis & $1,8 \pm 0,4$ & $1,5 \pm 0,2$ & $1,6 \pm 0,2$ & + & + & + & Peloreophil \\
\hline & Total: & 10 & 3 & 9 & 3 & 4 & 9 & \\
\hline
\end{tabular}


It should be noted that as a result of acclimatization and reproduction of these fish species in the fisheries near the Sangzordarya basin, the influx of white grasses and sandpipers into the river under human influence has led to the spread of Sinanodonta species in the Sangzordarya River.The densities of Colletopterum cyreum sogdianum, C.pondersum volgense, Colletopterum kokandicum and $\mathrm{C}$. bacterium are $0.7-2.4$ per $1 \mathrm{~m} 2$ in the beginning of the channel, while in the middle only Colletopterum cyreum sogdianum occur 1.8 per $1 \mathrm{~m} 2$ per [ 6].

In the beginning of the channel, the Sorbiculidae family Corbicula cor, S.purpurea, C.fluminalis, Corbiculina ferghanensis and, C.tibetensis species are distributed in sandy and rocky soils at 2.2-3.5 per $1 \mathrm{~m} 2$. We can take the example of Corbiculina ferghanensis, one of the species with the highest density in the channel. Its density is 3.5 per $1 \mathrm{~m} 2$ at the beginning of the channel and 1.4 at the bottom. Corbiculina tibetensis, C.ferghanensis species distributed in the aquatic ecosystem have been identified as eurybiont species. According to the ecological groups of bivalve mollusks, 8 species of peloreophiles (Corbicula cor, S. purpurea, S.fluminalis, CorbiculinaAccording to the ecological groups of bivalve mollusks, 8 species of peloreophiles (Corbicula cor, $S$. purpurea, S.fluminalis, Corbiculina tibetensis, C.ferghanensis, Sinanodonta gibba, S.orbicularis, S. puerorum) are common in the Tuyatortar channel and they account for $67 \%$ of the total mollusks. Rheophiles include 2 species (Colletopterum syreum sogdianum, C. bacterianum) (16.5\%), 2 species (Colletopterum ponderosum volgense, Colletopterum kokandicum), pelolemnofil (16.5\%).

Jizzakh Reservoir Access Channel - This channel was commissioned in 1973 in the
Sangzor River basin and provides water to more than 838,000 hectares. The total length of the canal is more than $18.4 \mathrm{~km}$ and $6.4 \mathrm{~km}$. It was concreted. The water capacity of the canal is $50 \mathrm{~m} 3 / \mathrm{sec}$. As a result of our research in the channel, 8 species and 2 subspecies of bivalve mollusks were found to belong to two families and 4 genera (Table 3.3.3.1). Three types were distributed in rocky soils, 4 types in sandy soils and 9 types in muds of the canal (Table 2).

The water of the Zarafshan River is deposited in the Sangzor River, and along with the water, the bivalve mollusks scattered on the banks of the Zarafshan River flow into the Sangzor River. The entrance to the Jizzakh Reservoir receives water from the Sangzor River. The fauna of this channel bivalve mollusk has not been specifically studied so far. Sinanodonta gibba, S. orbicularis, and $S$. puerorum pertaining to the genus Sinanodonta of the family Uonionidae are distributed in the muddy biatopes of the channel and in the surrounding ponds, and their density is 1.11.6 per $1 \mathrm{~m} 2$. Among these species, $\mathrm{S}$. orbicularis is distinguished by its large density, the density of which is 1.4 . In the middle part of the channel these species are not found, but in the biatopes of the lower part Sinanodonta gibba, S. orbicularis is distributed from 0.9-1.2 per $1 \mathrm{~m} 2$.

In the beginning of the channel, Colletopterum cyreum sogdianum and $\mathrm{C}$. ponderosum volgense from Colletopterum seeds were propagated from 0.5-1.1. In the lower part, Solletopterum cocandicum and C. ponderosum volgense occur in $0.6-0.8$ per 1 $\mathrm{m} 2$.

The presence of 3 different ecological groups in the channel was studied, 8 species of peloreophiles which includes $80 \%$ (Corbicula cor, S. purpurea, S.fluminalis, Corbiculina tibetensis, C.ferghanensis, Sinanodonta 
gibba, S.orbicularis, S. puerorum), 1 species of rheophiles which includes $10 \%$ (Colletopterum syreum sogdianum) and $1 \%$ of pelolimnophiles which includes 10\% (Colletopterum ponderosum volgense). Furthermore, 10 species and 2 subspecies of bivalve mollusks were found in the Tuyatortar canal, 8 species and 2 subspecies were found in the Jizzakh channel.

\section{References}

1. Danilin, D. D. Fauna, distribution, ecology of bivalves found on the shelf of Kronotskiy gulf in may 2012 // Mollusks of the Eastern Asia and Adjacent Seas: Abstracts the conf. (October 6-8, 2014, Vladivostok, Russia). - Vladivostok: Dalnauka, 2014. - C. 13-14.

2. Boymurodov Kh.T. The degree of content of natural radionuclides in mollusks // Uzbek Biological journal. -Ташкент, 2011. -№5. -P. 41-42.

3. Боймуродов Х.Т. Двустворчатые моллюски водоёмов Узбекистана как объект экологического мониторинга // Журнал Московское Общество Испытателей Природы. -Москва, 2015. - C.9-11.

4. Boymurodov Kh.T. Development of Producing Pearl of Bivalve Molluses (Mollusca: Unionidae, Corbuculidae) in Uzbekistan // Eastern European Scientific Journal. -Germany, 2015. -№4. -P. 4447.

5. Boymurodov Kh.T. Two Subspecies Mollusks Fauna, Biologic Difference and Ecologic Groups in the Water Reservoirs in Nearby Mountain // Eastern European Scientific Journal. -Germany, 2015. -№5. -P.15-19.

6. Иззатуллаев 3.И., Боймуродов Х.Т. Результаты выращивания жемчуга двустворчатых пресноводных моллюсков (Bivalvia: Unionidae,Anadontinae) Узбекистана// Журнал Московское Общество ИспытателейПрироды. -Москва, 2016. т. 121. вып. 5 с.16-19.

\section{How to cite this article:}

Boymurodov, X. T. and Toynazarova, I. A 2021. Density, Biotope Distribution and Ecological Groups of Bivalve Mollusks in the Access Channels to Tuyatortar and Jizzakh Reservoirs. Int.J.Curr.Microbiol.App.Sci. 10(02): 117-121. doi: https://doi.org/10.20546/ijcmas.2021.1002.014 